\title{
Physico-Chemicals Characterization of Quercetin from the Carica papaya Leaves by Different Extraction Techniques
}

\author{
Muhammad Hidhir Khawory 1,2*, Mohd Ferdaues Mohd Subki1,2, Mohd Anuar Shahudin1,2, \\ Nurul Hidayatul Afifah Saufi Sofian 1,2, Nur Hidayah Latif ${ }^{1,2}$, Nurul Hanim Salin ${ }^{1,2}$, \\ Siti Zuraidah Mohamad Zobir ${ }^{1,2}$, Mohamed Ibrahim Noordin ${ }^{3}$
}

\author{
${ }^{1}$ Malaysian Institute of Pharmaceutical and Nutraceutical (IPharm), Pulau Pinang, Malaysia \\ ${ }^{2}$ National Institutes of Biotechnology Malaysia (NIBM), Selangor, Malaysia \\ ${ }^{3}$ PICOMS International University College, Kuala Lumpur, Malaysia \\ Email: *muhammad_hidhir@nibm.my
}

\begin{abstract}
How to cite this paper: Khawory, M.H., Mohd Subki, M.F., Shahudin, M.A., Saufi Sofian, N.H.A., Latif, N.H., Salin, N.H., Mohamad Zobir, S.Z. and Noordin, M.I. (2021) Physico-Chemicals Characterization of Quercetin from the Carica papaya Leaves by Different Extraction Techniques. Open Journal of Physical Chemistry, 11, 129-143. https://doi.org/10.4236/ojpc.2021.113007
\end{abstract}

Received: March 31, 2021

Accepted: June 25, 2021

Published: June 28, 2021

Copyright @ 2021 by author(s) and Scientific Research Publishing Inc. This work is licensed under the Creative Commons Attribution International License (CC BY 4.0).

http://creativecommons.org/licenses/by/4.0/

\section{(c) (i) Open Access}

\begin{abstract}
Carica papaya leaf extracts from four different extraction methods (cold-water, hot-water, sonication and supercritical fluid), were characterized using physico-chemical analysis. Sonication extraction showed the highest percentage yield of crude extracts $(6.76 \%)$ and the lowest from the supercritical fluid extraction (1.83\%). The Infrared (IR) spectrum of cold-water extract demonstrated the most similarity of functional group to quercetin. Likewise, the thermal analysis indicated that cold-water extract gave a quite similar Endothermic peak to quercetin with the obtained value which was $137^{\circ} \mathrm{C}$ and onset value which was $118^{\circ} \mathrm{C}$. The liquid chromatography (LC) profile indicated that only the cold-water extract exhibited $0.203 \mathrm{ppm}$ of quercetin.
\end{abstract}

\section{Keywords}

Carica papaya, Extraction, Infrared, Liquid Chromatography, Thermal Analysis

\section{Introduction}

Carica papaya is a tropical plant with a powerhouse of nutrients and is available throughout the year. The young leaves, shoots, and fruits are used in cooking. The fruits are a source of flavouring for candies, jellies, preserves, and ice creams [1]. Traditionally, this plant has been used for the treatment of acne, skin infection, wound, anti-aging, poor vision, anthelmintic, constipation, colon cancer, hypertension, weak immune system and dengue fever [2]. The nutritional and medicinal values of the plant come from the presence of various enzymes and 
compounds [3].

Quercetin is a biflavonoid that is usually found in many plants including $\mathrm{Ca}$ rica papaya. [4] reported that the existence of quercetin in Carica papaya leaves promotes anti-dengue activities. The leaf extract is generally prescribed for patients with dengue fever, but scientific pieces of evidence for the anti-dengue activities are still limited. Flavonoid such as quercetin was reported to possess a high inhibitory effect towards dengue [5]. Quercetin has the ability to inhibit the platelet aggregation, which promotes anti-dengue activities [6]. Several analytical techniques have been developed for identification and quantification of flavonoids such as gas chromatographic (GC), mass spectrometry, thin layer chromatography, UV spectrometry, high-performance liquid chromatography (HPLC) and infrared spectroscopy [7].

FTIR is techniques based on the vibrations of the atoms of a molecule which are no two compounds produce the exact same infrared spectrum because each different material is a unique combination of atoms [8]. Furthermore, measurements made by FTIR are accurate and reproducible due to their sensitivity, speed, internally calibrated and mechanical simplicity. DSC is a technique for determining thermodynamic properties of biomacromolecules with the ability to provide detailed information about both the physical and energetic properties of a substance [9].

HPLC is the most widely used of all of the analytical separation techniques due to its sensitivity, its ready adaptability to accurate quantitative determinations, its ease of automation, its suitability for separating non-volatile species or thermally fragile ones as well as its widespread applicability to substances that are important to the industry, many fields of science and the public [10]. Therefore, the combination of several spectroscopy methods is proposed to enrich the identification and quantification of the compound. In this study, we combined three spectroscopic techniques (FTIR, DSC and HPLC) to identify and quantify quercetin from the extract of Carica papaya leaves. Thus, identifying the amount of quercetin in Carica papaya leaves extract could further explain the pharmacological properties of the plant.

\section{Materials \& Methodology}

\subsection{Materials}

Plant samples of Carica papaya were supplied by d'Cultivate Resources Sdn. Bhd. and obtained from Desasiwa RST, Universiti Sains Malaysia (USM), Penang. The plant was identified by Dr. Rahmad Zakaria, botanist from School of Biological Sciences, Universiti Sains Malaysia, Penang with the voucher specimen is IPNAT203A. The leaves of plant samples were washed and packed in 1 kilogram per bag for each different extraction method.

\subsection{Extraction}

To determine the optimal extraction method of Carica papaya leaves, four dif- 
ferent methods were tested, which were cold-water extraction, hot-water extraction, sonication and supercritical fluid extraction (SFE).

\subsubsection{Cold Water Extraction}

$1 \mathrm{~kg}$ of ground leaves samples was added with $5 \mathrm{~L}$ ultra-pure water and the extract was filtered and transferred into a plastic bag. The extract was stored in $-20^{\circ} \mathrm{C}$ freezer. The frozen sample was then transferred into a freeze-dry vessel followed by lyophilization process to powder using a freeze dryer machine (CHRiST $^{\circledR}$, ALPHA 1-2 LD). The powder was then collected, weighted and stored in a labeled bottle and kept at $-20^{\circ} \mathrm{C}$ for further usage.

\subsubsection{Hot Water Extraction}

$1 \mathrm{~kg}$ of ground leaves samples was added with $5 \mathrm{~L}$ ultra-pure water and heated to $40^{\circ} \mathrm{C}$ for 3 hours and let it cooling down to room temperature and filtered using cloth. The extract was packed into a plastic bag and stored in a $-20^{\circ} \mathrm{C}$ freezer. The frozen sample was then transferred into a freeze-dry vessel followed by lyophilization process to powder using a freeze dryer machine (CHRiST ${ }^{\circledR}$, ALPHA 1-2 LD). The powder extracts was then collected, weighted, stored in a labeled bottle and kept at $-20^{\circ} \mathrm{C}$ for further usage.

\subsubsection{Sonication}

$1 \mathrm{~kg}$ of the leaves was grounded with $1.25 \mathrm{~L}$ ultra-pure water. The ground sample was transferred into 4 units of $1000 \mathrm{~mL}$ beaker and sonicated for 1 hour. The extract was filtered and transferred into a plastic bag. The filtered extract was stored in $-20^{\circ} \mathrm{C}$ freezer and further lyophilized to powder. The powder was then collected, weighted and stored in a labeled bottle and kept at $-20^{\circ} \mathrm{C}$ for further usage.

\subsubsection{Supercritical Fluid Extraction (SFE)}

$109 \mathrm{~g}$ of leaves samples was sent to an analytical service company, Renetech Sdn Bhd (734686-H) (formerly known as Renetech Scientific Sdn Bhd) for the supercritical fluid extraction (DELTA, Taiwan) service. In this study, fixed extraction parameters were optimized at temperature of $50^{\circ} \mathrm{C}$, pressure of 3626 psi for 5 hours.

\subsection{Fourier Transform Infrared (FTIR) Analysis}

$2 \mathrm{mg}$ of each extract (hot, cold, sonication and supercritical fluid) and standard compound, quercetin (SIGMA-ALDRICH, USA) with $\geq 95 \%$ were analyzed using Attenuated Total Reflectance (ATR) crystal, Perkin Elmer FT-IR C103470 (Spectrum Two DTGS) with a scan (16 scans) range from 4000 to $450 \mathrm{~cm}^{-1}$ (mid-infrared) at resolution of $4 \mathrm{~cm}^{-1}$.

\subsection{Differential Scanning Calorimetry (DSC) Analysis}

Diamond DSC (Perkin Elmer, USA) was used for thermal analysis. The type of pan used was standard aluminium pans (158003) and covers (160955). The scan- 
ning program used for all components was Isothermal for 1 minute at $-20^{\circ} \mathrm{C}$ and scanning from $-20^{\circ} \mathrm{C}$ to $300^{\circ} \mathrm{C}$ at the scanning rate of $10^{\circ} \mathrm{C} / \mathrm{min}$. Every sample was scanned three times and both mean and $\mathrm{SD}$ were calculated for the melting characteristic namely the melting point $\left({ }^{\circ} \mathrm{C}\right)$ and the energy used (Delta $\mathrm{H})$ in the melting process $(\mathrm{J} / \mathrm{g})$.

\subsection{Thermogravimetric (TGA) Analysis}

$20 \mathrm{mg}$ of four sample carica papaya extract and one standard compound quercetin were send to USAINS Biomics Laboratory Testing Services Sdn. Bhd (937636-D) (formerly known as Usains Biomics Sdn Bhd). Thermogravimetric analysis using Perkin Elmer TG/DTA analyzer (STA 6000, Massachusetts, U.S.A) operating in the range of $25^{\circ} \mathrm{C}$ to $300^{\circ} \mathrm{C}$ with at temperature rise of $10.00^{\circ} \mathrm{C} / \mathrm{min}$ and flow of nitrogen gas is $10 \mathrm{~mL} / \mathrm{min}$.

\subsection{High Performance Liquid Chromatography (HPLC) Analysis}

\subsubsection{Sample Preparation}

All extracts were dissolved in methanol HPLC grade to obtain $1000 \mathrm{ppm}$ concentration in methanol and filtered using $0.45 \mu \mathrm{m}$ PTFE filter prior to HPLC analysis.

\subsubsection{Standard Curve}

Stock solution of quercetin standard (SIGMA-ALDRICH, USA) with $\geq 95 \%$ was prepared at $10 \mathrm{ppm}$ and the standard curve was constructed (Table 1) from 0.2 ppm to $1.6 \mathrm{ppm}$. The standard solutions were filtered using $0.45 \mu \mathrm{m}$ PTFE filter prior to HPLC analysis. The standard curve was obtained by plotting peak area versus concentration of each standard

\subsubsection{HPLC Setting}

The HPLC (Agilent 1260 Infinity with Eclipse Plus-Column C18 $(4.6 \mathrm{~mm} \times 150 \mathrm{~mm}$ I.D., $5 \mu \mathrm{m}$ particle size) was used in this analysis. Parameter setting at a Flow rate of $1 \mathrm{~mL} / \mathrm{min}, 10 \mu \mathrm{L}$ of injection volume with mobile phase consisted of (A) $0.1 \%$ orthophosporic acid and (B) 100\% methanol using gradient elution mode. The mobile phase was started with $0.1 \%$ orthophosporic (A) at $0-5 \min (80 \%-60 \%)$, 5 - $10 \min (60 \%-40 \%), 10-15 \min (40 \%-35 \%), 15-20 \min (35 \%-20 \%)$ and 20 - $25 \mathrm{~min}(20 \%-80 \%)$. The samples and quercetin standards were detected at UV

Table 1. The volume of stock solution and methanol at concentration of $0.2 \mathrm{ppm}$ to 1.6 ppm.

\begin{tabular}{ccc}
\hline Concentration $(\mathrm{ppm})$ & Volume of stock solution $(\mu \mathrm{L})$ & Volume of methanol $(\mu \mathrm{L})$ \\
\hline 0.2 & 20 & 980 \\
0.4 & 40 & 960 \\
0.8 & 80 & 920 \\
1.0 & 100 & 900 \\
1.6 & 160 & 840 \\
\hline
\end{tabular}


wavelengths of $280 \mathrm{~nm}$ and $372 \mathrm{~nm}$, respectively. The optimized chromatographic method was validated according to [10].

\section{1) Specificity}

Specificity of the HPLC method was observed by the separation of the analytes. A volume of $10 \mu \mathrm{L}$ of quercetin was injected and the chromatogram was recorded.

\section{2) Linearity}

The linearity was conducted based on a standard curve by plotting peak area versus concentration of quercetin where the square of the correlation coefficient $\mathrm{R}^{2}>0.99$ is indicative of the linearity.

\section{3) Repeatability}

The repeatability of the proposed method was conducted by injecting three replicates of $0.4 \mathrm{ppm}$ concentration. The peak area was calculated based on the standard curve within the Beer's range. Percentage of relative standard deviation (RSD) was calculated based on the peak area.

\section{4) Limit of detection (LOD) and limit of quantification (LOQ)}

The LOD and LOQ were determined by using the formula based on the standard deviation of response and slope.

$$
\begin{aligned}
& \mathrm{LOD}=3.3(\sigma) / \mathrm{S} \\
& \mathrm{LOQ}=10(\sigma) / \mathrm{S}
\end{aligned}
$$

where $\sigma$ is the standard deviation of response and $\mathrm{S}$ is the slope of the calibration curve.

\subsubsection{Quantification of Quercetin in Sample}

The quantification of quercetin in the cold-water extract, hot-water extract, sonication water extract and supercritical fluid extraction was based on the standard curve.

\section{Results \& Discussion}

\subsection{Extraction of Carica papaya Leaves}

Four different extraction methods involved in this study are hot water, cold water, sonication and supercritical fluid. Table 2 shows the sonication method produced the highest percentage yield, which is $6.76 \%$ followed by cold water (5.78\%), hot water $(3.22 \%)$ and supercritical fluid extraction (1.83\%) respectively. Even though the sonication method produced the highest yield, the cold-water method is more preferable for further analysis because no heat was applied that

Table 2. Percentage yield of four different extraction methods.

\begin{tabular}{cccccc}
\hline Extraction Method & Hot Water & Cold Water & Sonication & Supercritical Fluid \\
\hline Weight of Carica papaya leaves $(\mathrm{kg})$ & 1 & 1 & 1 & 0.109 \\
Weight of extraction $(\mathrm{kg})$ & 0.0322 & 0.0578 & 0.0677 & 0.002 \\
Percentage of Yield (\%) & 3.22 & 5.78 & 6.76 & 1.83 \\
\hline
\end{tabular}


may change the morphological structures as well as an active chemical constituents inside the sample, which may result in compound degradation [11].

\subsection{Fourier Transform Infrared (FT-IR) Analysis}

The spectral data of the comparison between the four different extraction methods and the standard compound, quercetin can be found in Figure 1 and the summary of each spectrum is listed in Table 3.

The FTIR spectroscopy was used to investigate the possible chemical compounds in the sample because it is the most suitable technique of the non-destructive spectroscopic methods [12]. Quercetin is a plant polyphenol from the flavonoid group. The functional group of quercetin is phenol with the hydrogen bonded $\mathrm{O}-\mathrm{H}$ stretch from the range $3600-3100 \mathrm{~cm}^{-1}$ where it can be found in all extracts (Table 3) but not in supercritical fluid extraction method. Among the functional groups observed in all extracts, - $\mathrm{OH}$ group was found to be present uniformly in the water extracts. Based on the spectrum, the cold-water extract showed the most similar functional group to quercetin. Meanwhile, the hot-water extract showed the missing one functional groups of $\mathrm{C}-\mathrm{O}$ stretch and $\mathrm{C}-\mathrm{C}=\mathrm{C}$ asymmetric stretch as well as sonication extract. This can be deduced from the hot water extraction may denature the protein structure and cause the permanent structure denaturation and reducing the flavonoid property of quercetin [13]. Meanwhile, for the supercritical fluid extract, there is missing peak of $\mathrm{O}-\mathrm{H}$ stretch due to no solvent was applied in the extraction process. In addition, there is an additional $\mathrm{C}-\mathrm{H}_{3}$ bend which was suggested from the $\mathrm{CO}_{2}$ supply

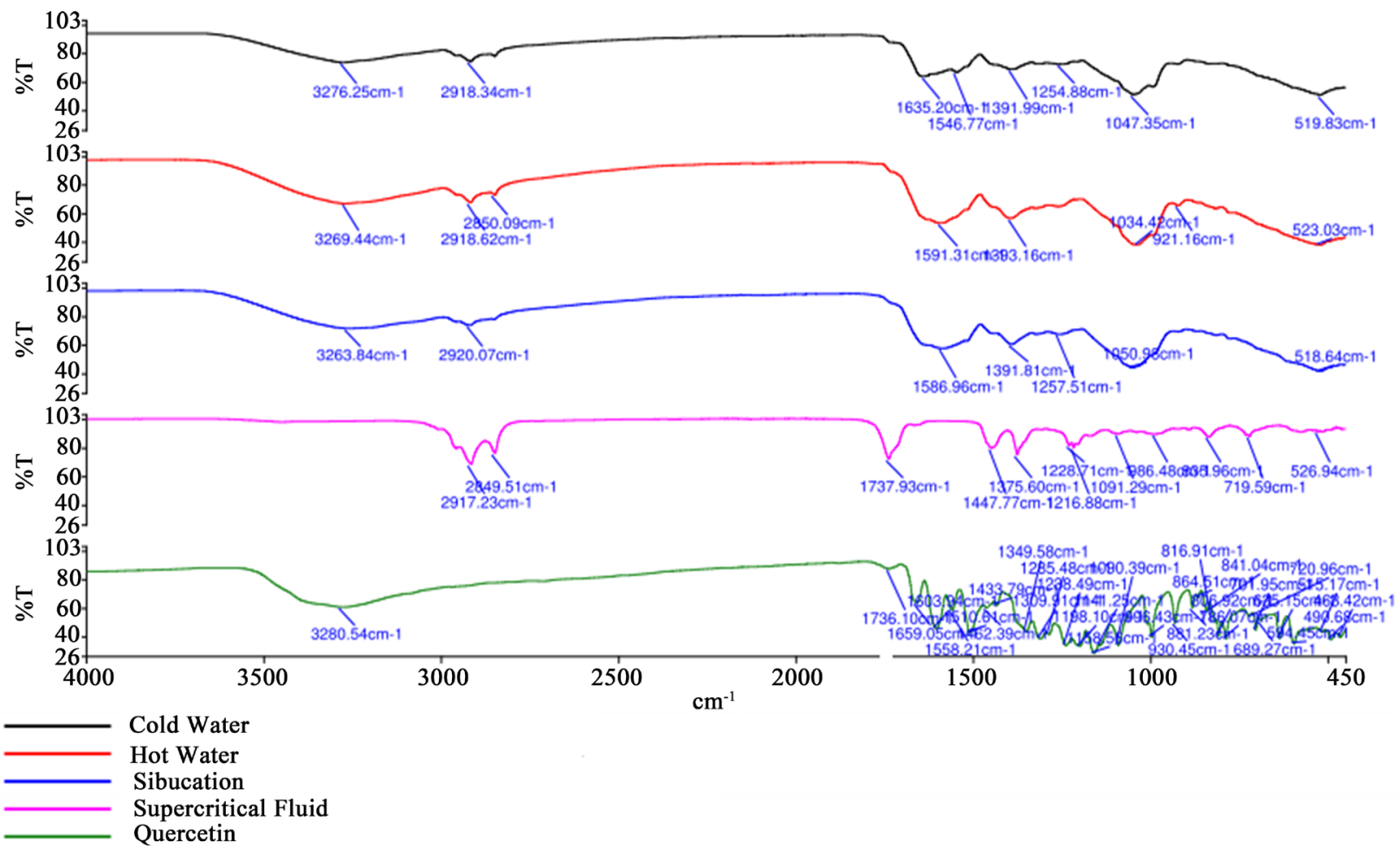

Figure 1. Comparison between quercetin and four different extraction methods. 
Table 3. FTIR spectral peak values and functional groups between quercetin and four different extraction methods.

\begin{tabular}{|c|c|c|}
\hline Sample & Peak Values $\left(\mathrm{cm}^{-1}\right)$ & Functional Groups \\
\hline \multirow{5}{*}{ Quercetin } & 3280.54 & $\mathrm{O}-\mathrm{H}$ stretch \\
\hline & 1736.10 & $\mathrm{C}=\mathrm{O}$ stretch \\
\hline & $1659.05 / 1603.94$ & $\mathrm{C}-\mathrm{C}=\mathrm{C}$ symmetric stretch \\
\hline & 1558.21 & $\mathrm{C}-\mathrm{C}=\mathrm{C}$ asymmetric stretch \\
\hline & 1462.39 & $\mathrm{C}-\mathrm{H}_{2}$ bend \\
\hline H & $1238.49 / 1091.39$ & $\mathrm{C}-\mathrm{O}$ stretch \\
\hline & $930.45 / 701.95$ & C-H bend \\
\hline \multirow{7}{*}{ Cold Water } & 3276.25 & $\mathrm{O}-\mathrm{H}$ stretch \\
\hline & 2918.34 & $\mathrm{H}-\mathrm{C}-\mathrm{H}$ stretch \\
\hline & 1635.20 & $\mathrm{C}-\mathrm{C}=\mathrm{C}$ symmetric stretch \\
\hline & 1546.77 & $\mathrm{C}-\mathrm{C}=\mathrm{C}$ asymmetric stretch \\
\hline & 1391.99 & $\mathrm{C}-\mathrm{H}_{2}$ bend \\
\hline & $1254.88 / 1047.35$ & C-O stretch \\
\hline & 519.83 & $\mathrm{C}-\mathrm{H}$ bend \\
\hline \multirow{6}{*}{ Hot Water } & 3269.44 & $\mathrm{O}-\mathrm{H}$ stretch \\
\hline & $2918.62 / 2850.09$ & H-C-H stretch \\
\hline & 1591.31 & $\mathrm{C}-\mathrm{C}=\mathrm{C}$ symmetric stretch \\
\hline & 1393.16 & $\mathrm{C}-\mathrm{H}_{2}$ bend \\
\hline & 1034.42 & $\mathrm{C}-\mathrm{O}$ stretch \\
\hline & $921.16 / 523.03$ & C-H bend \\
\hline \multirow{6}{*}{ Sonication } & 3263.84 & $\mathrm{O}-\mathrm{H}$ stretch \\
\hline & 2920.07 & H-C-H stretch \\
\hline & 1586.96 & $\mathrm{C}-\mathrm{C}=\mathrm{C}$ symmetric stretch \\
\hline & 1391.81 & $\mathrm{C}-\mathrm{H}_{2}$ bend \\
\hline & $1257.51 / 1050.98$ & C-O stretch \\
\hline & 518.64 & C-H bend \\
\hline \multirow{6}{*}{ Supercritical Fluid } & $2917.23 / 2849.51$ & H-C-H stretch \\
\hline & 1737.93 & $\mathrm{C}=\mathrm{O}$ stretch \\
\hline & 1447.77 & $\mathrm{CH}_{2}$ bend \\
\hline & 1375.60 & $\mathrm{CH}_{3}$ bend \\
\hline & $1228.71 / 1091.29$ & C-O stretch \\
\hline & $986.48 / 719.59$ & $\mathrm{C}-\mathrm{H}$ bend \\
\hline
\end{tabular}

during extraction process. Hence, the cold-water extraction method shows an enriched identification of quercetin as an active ingredient in the Carica papaya leaves.

\subsection{Differential Scanning Calorimetry (DSC) Analysis}

DSC was used to determine the thermal characteristics of each sample to suggest 
the possibility of incompatibilities and interactions [14]. The results are predictive by interpreting the thermogram of each component and the mixture of the components [15]. The diagram (Figure 2) depicts the thermogram of each extraction method.

The DSC curves for SFE extract show that thermal processes occurred at onset temperature $62.61^{\circ} \mathrm{C}$. The presence of endothermic event at $66.49^{\circ} \mathrm{C}(\mathrm{D}=3.2761$ $\left.\mathrm{J} \cdot \mathrm{g}^{-1}\right)$ is observed, which is probably related to the loss of volatile constituents of the sample, such as water [16]. DSC curves for sonication extract shows that thermal processes occurred at onset temperature $112.90^{\circ} \mathrm{C}$ with the presence of endothermic event at $135.02^{\circ} \mathrm{C}\left(\mathrm{D}=-26.3375 \mathrm{~J} \cdot \mathrm{g}^{-1}\right)$ was observed. DSC curves for cold-water and hot-water extract shows that thermal processes occurred at near onset temperature which is $118.77^{\circ} \mathrm{C}$ and $117.04^{\circ} \mathrm{C}$ respectively but with different endothermic event at $137.71^{\circ} \mathrm{C}\left(\mathrm{D}=-33.11 \mathrm{~J} \cdot \mathrm{g}^{-1}\right)$ for cold water extract and endothermic event at $118.16^{\circ} \mathrm{C}\left(\mathrm{D}=1.4177 \mathrm{~J} \cdot \mathrm{g}^{-1}\right)$ for hot-water extract.

When compared to quercetin, the cold-water extraction method was the optimal method. The Endothermic peak between the method and quercetin standard is quite similar, which they obtained value is $137^{\circ} \mathrm{C}$ and onset value is $118^{\circ} \mathrm{C}$. Despite, the thermogram of each extraction method shows reproducibility, and the cold-extraction method demonstrates the optimal reproducibility.

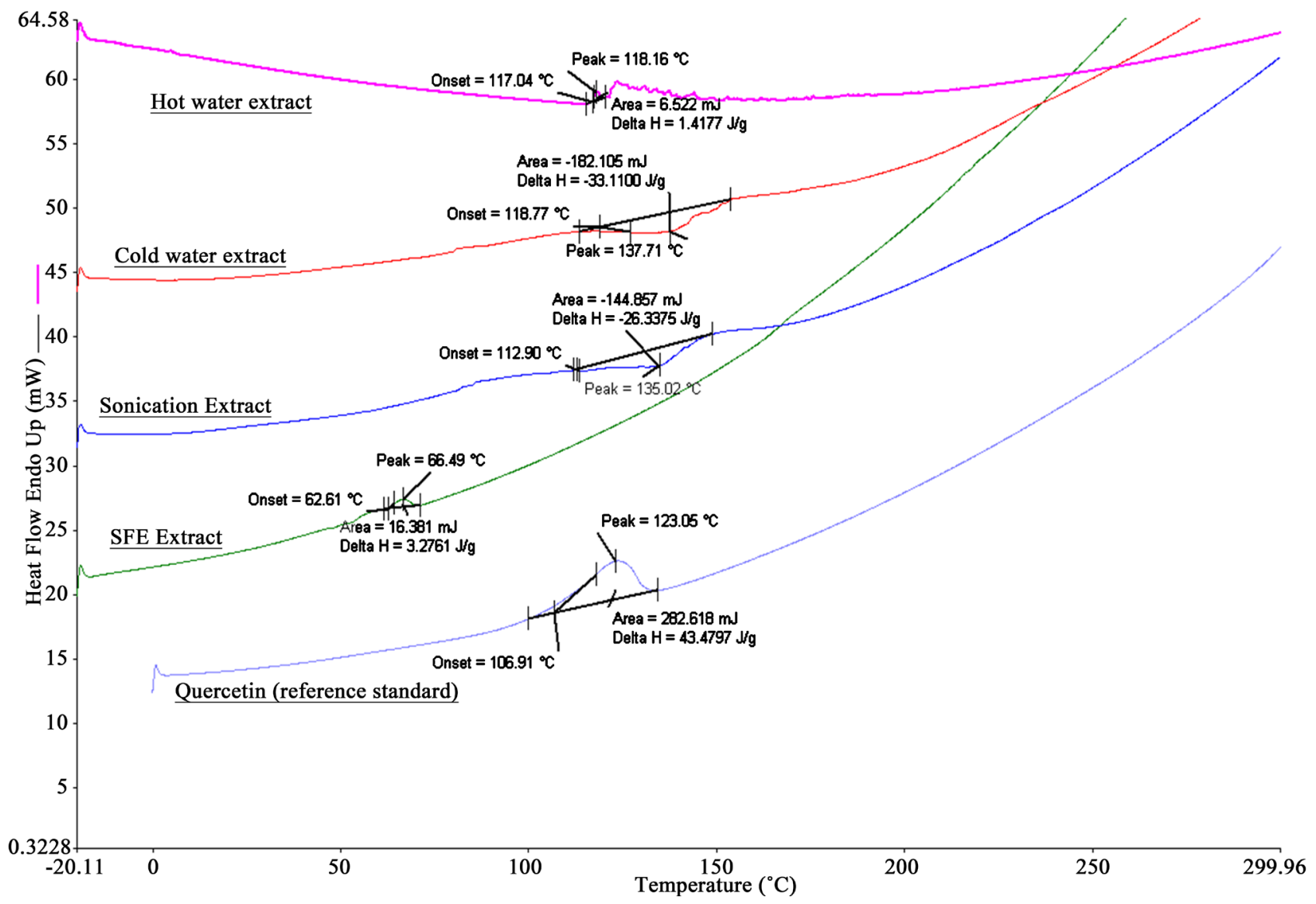

Figure 2. Thermogram of quercetin and four different extracts from different extraction methods. 


\subsection{Thermogravimetric (TGA) Analysis}

Thermogravimetric analysis (TGA) is an evaluation technique that measures different substance masses as their temperature is changed or at a constant temperature over a given time. It is used to analyze decomposition and evaporation rates, oxidation, material purity and many other properties. The thermal behavior of the different Carica papaya extract is shown in Figure 3 that represents thermal behavior of the standard compound (quercetin) as a marker.

Overall, the TGA curve shows that the sample decomposes in three major steps within the temperature range $25^{\circ} \mathrm{C}-300^{\circ} \mathrm{C}$. The first mass loss, takes place between $30^{\circ} \mathrm{C}-98^{\circ} \mathrm{C}$, results in $0.7 \%$ may be attributed to the loss of adsorbed and structural water of excipient or due to desorption of moisture as hydrogen-bond water to the polysaccharide structure [17].

The second weight loss event take place between $99^{\circ} \mathrm{C}-113^{\circ} \mathrm{C}$, resulted in weight loss of about $1.8 \%$, may be attributed to the excipient decomposition (maximum oxidation or decomposition temperature) [18].

The third weight loss event takes place between $115^{\circ} \mathrm{C}-300^{\circ} \mathrm{C}$, results in a weight loss of about $97.5 \%$. A major weight loss (97.5\%) takes place attributed to the complete decomposition of plant extract. Therefore, the calcination temperature for the preparation of the extract was chosen to be $250^{\circ} \mathrm{C}$ that cover the temperature region from above the major decomposition region at $200^{\circ} \mathrm{C}$ to $300^{\circ} \mathrm{C}$, where a stable mass was obtained [19].

\subsection{High Performance Liquid Chromatography (HPLC) Analysis of Quercetin}

The validation method of HPLC analysis comprises specificity, linearity, repeatability, limit of detection and limit of quantification. Figure 4(b) indicates a single peak of standard quercetin detected at $12.568 \mathrm{~min}$ at wavelength $372 \mathrm{~nm}$. Based on Figure 4(a), the correlation coefficient, $R^{2}$ was found to be 0.9996 with the slope at 36.247 and the intercept at 1.551 . LOD and LOQ were found to be $0.0277 \mathrm{ppm}$ and 0.0841 ppm respectively. The percentage of RSD (Table 4 ) is $0.371 \%$ for repeatability of quercetin. The acceptance criterion for precision is less than $2 \%$ of RSD value.

All extracts were analyzed using HPLC method to detect the presence of quercetin. The quantification of each extract was determined respectively (Table 5). Based on the HPLC profile (Figures 4(c)-(f)), only the cold water extract exhibited $0.203 \mathrm{ppm}$ quercetin compares to hot-water extract, sonication extract and supercritical fluid extract which indicate none of the compound itself. The difference of extraction conditions will affect the yield of quercetin. [20] reported that isolation of quercetin using the cold condition is more effective, contradicts to the thermal processing condition, which could also cause the loss of natural bioactive properties [21].

\section{Conclusion}

To this end, the study found that the cold water extraction method showed the 
(a) 100.2

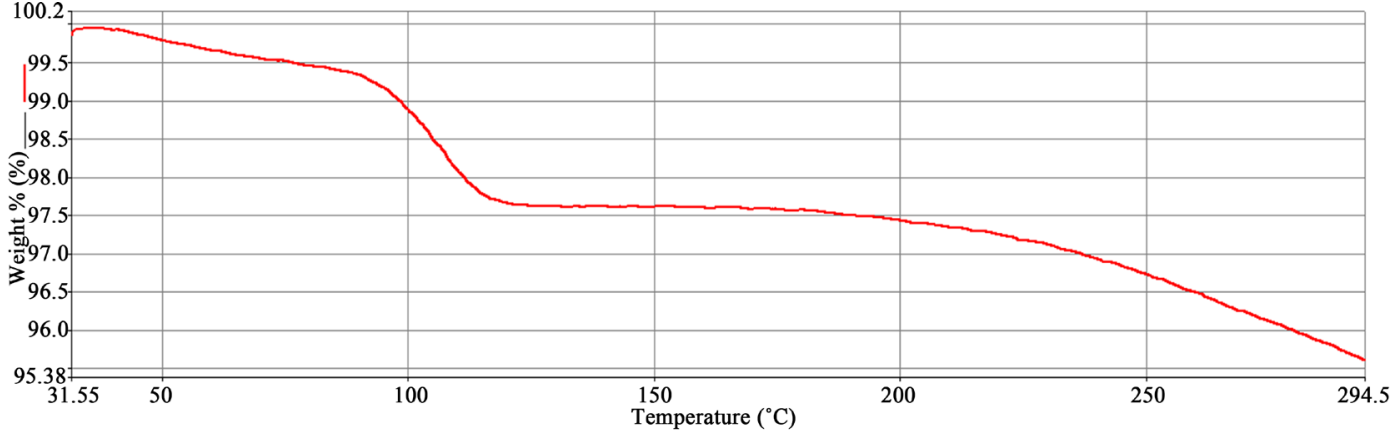

(b) 101

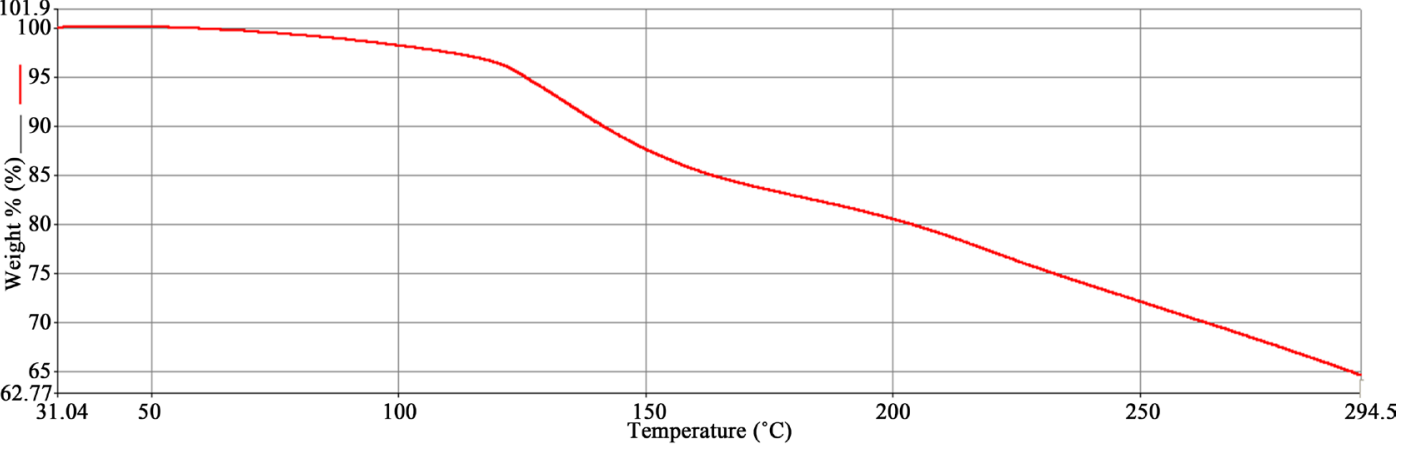

(c) 99

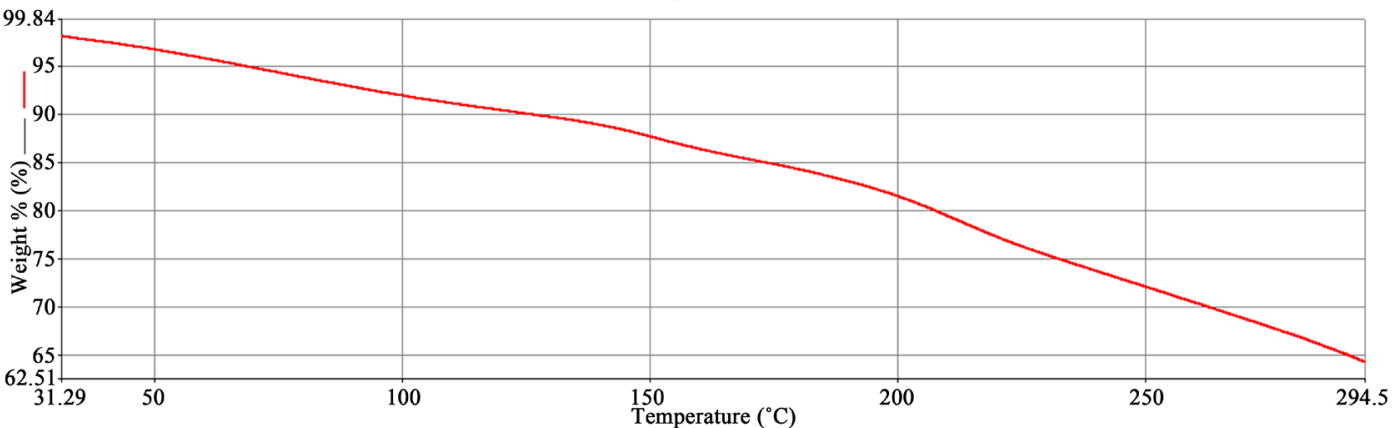

(d) 101

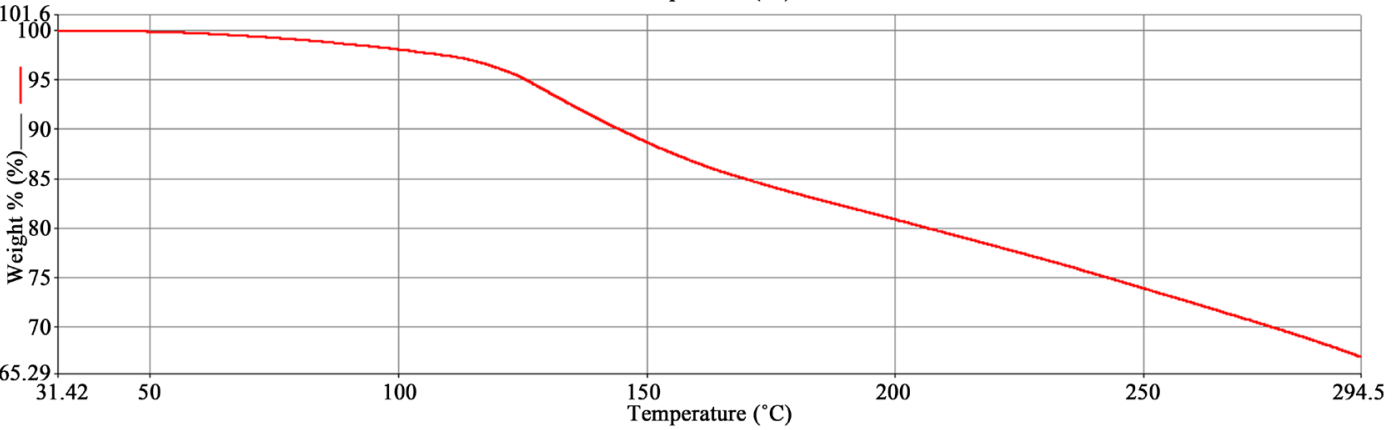

(e) 10

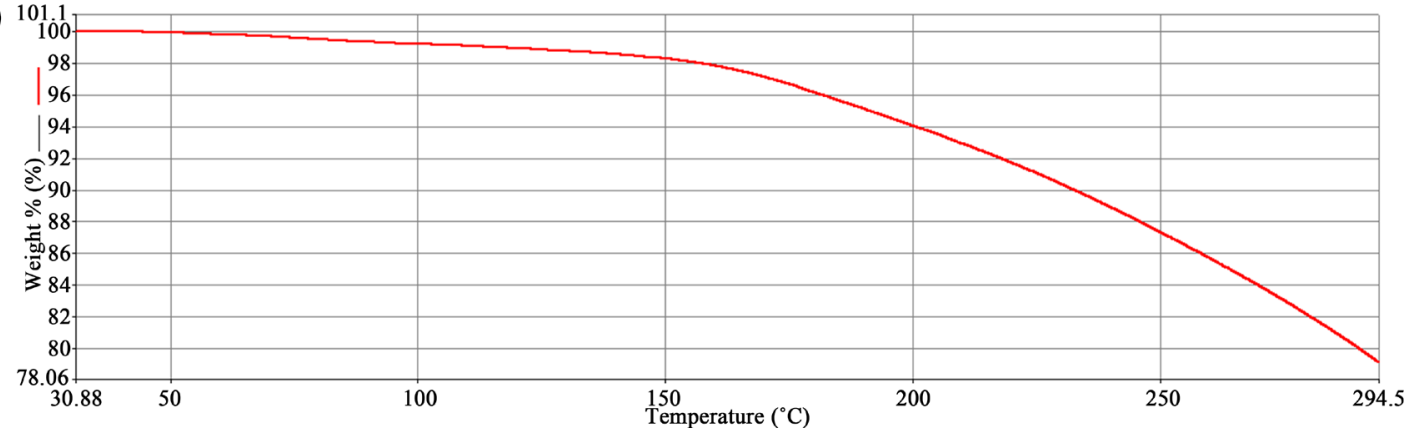

Figure 3. TGA Chromatogram of (a) Quercetin, (b) Hot water extraction, (c) Cold water extraction, (d) Sonification extraction and (e) Supercritical fluid extraction of Carica papaya. 

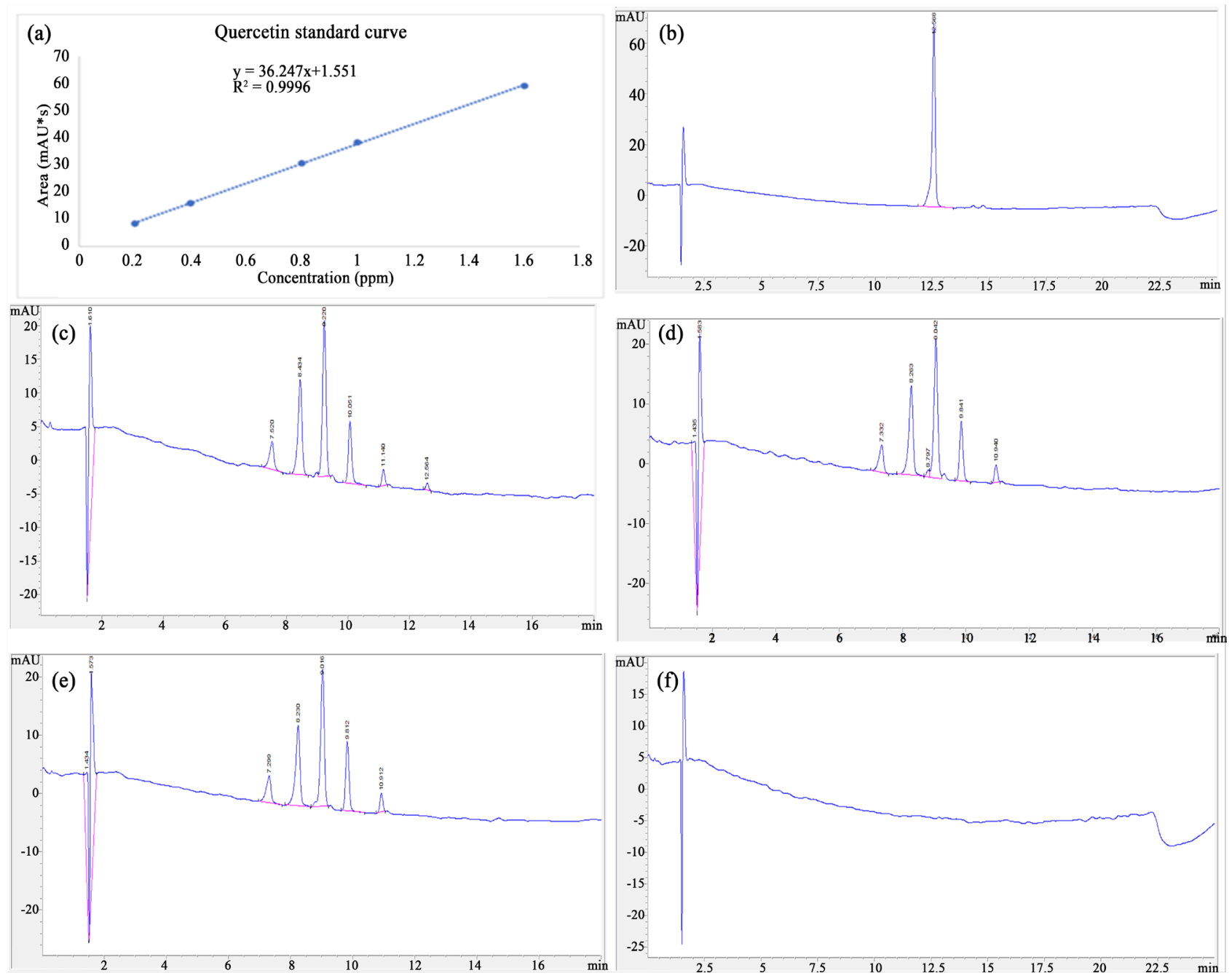

Figure 4. HPLC Chromatogram of (a) Standard curve of quercetin, (b) Quercetin, (c) Cold water extraction, (d) Hot water extraction, (e) Sonification extraction and (f) Supercritical fluid extraction of Carica papaya

Table 4. Repeatability of quercetin.

\begin{tabular}{cccccc}
\hline No & $\begin{array}{c}\text { Concentration } \\
(\mathrm{ppm})\end{array}$ & Peak area & Mean & $\begin{array}{c}\text { Standard } \\
\text { deviation }\end{array}$ & $\begin{array}{c}\text { Percentage of } \\
\text { RSD (\%) }\end{array}$ \\
\hline 1 & 0.4 & 16.0614 & & & \\
2 & 0.4 & 15.9924 & 15.99903 & 0.059329 & 0.370827 \\
3 & 0.4 & 15.9433 & & & \\
\hline
\end{tabular}

Table 5. Quantification of quercetin in different extraction methods.

\begin{tabular}{rcc}
\hline Type of extract & Area $\left(\mathrm{mAU}^{*} \mathbf{s}\right)$ & Amount of quercetin $(\mathrm{ppm})$ \\
\hline Cold water extract & 8.91896 & 0.203 \\
Hot water extract & $\mathrm{ND}$ & $\mathrm{ND}$ \\
Sonification extract & $\mathrm{ND}$ & $\mathrm{ND}$ \\
Supercritical fluid extract & $\mathrm{ND}$ & $\mathrm{ND}$ \\
\hline
\end{tabular}

ND indicates not detected. 
highest spectral similarities to quercetin from DSC thermogram and FTIR spectral. The quantification of quercetin in the cold-water extract indicated a 0.203 ppm yield, but was not determined in the other three extracts. Quercetin is sensitive to heat, thus no heat was applied using this method where active chemical constituent inside the sample can be preserved. Also, this method uses minimal electricity cost and time consumption. However, both hot water extract and sonification extract did not possess this flavanoid due to high temperature. Higher temperature causes the change in the protein structure and protein unfolding with the loss of activity which promotes to denaturation of the protein [22]. Even though supercritical fluid extraction (SFE) provides a range of benefits such as low critical temperature $\left(31^{\circ} \mathrm{C}\right)$, selectivity, inertness, non-toxicity, and capability to extract thermally labile compounds, but SFE also offers some of the limitations which include very expensive and complex equipment operating at elevated pressures, no polar substances are extracted and high power consumption. Hence, the cold-water extraction method was found to be the optimal extraction method and the identification and quantification of the extract are enriched from all three analytical techniques by showing the highest spectral analysis to quercetin. The extraction method and the combination of the analytical techniques can be used to standardize the extract, which is can be used in developing nutraceutical product specifically to the anti-dengue properties.

\section{Acknowledgements}

The authors acknowledged the financial support from Ministry of Science, Technology and Innovation (MOSTI) under the Technofund (PKA0514B006).

\section{Conflicts of Interest}

The authors declare no conflicts of interest regarding the publication of this paper.

\section{References}

[1] Boshra, V. and Tajul, A.Y. (2013) Papaya-An Innovative Raw Material for Food and Pharmaceutical Processing Industry. Health and the Environment Journal, 4, 68-75.

[2] Arvind, G., Bhowmik, D., Duraivel, S. and Harish, G. (2013) Traditional and Medicinal Uses of Carica papaya. Journal of Medicinal Plants Studies, 1, 2320-3862.

[3] Yogiraj, V., Goyal, P.K. and Chauhan, C.S. (2015) Carica papaya Linn: An Overview. International Journal of Herbal Medicine, 2, 1-8.

[4] David, A.V.A., Arulmoli, R. and Parasuraman, S. (2016) Overviews of Biological Importance of Quercetin: A Bioactive Flavonoid. Pharmacognosy Reviews, 10, 84-89. https://doi.org/10.4103/0973-7847.194044

[5] Zandi, K., Teoh, B., Sam, S., Wong, P., Mustafa, M.R. and Abubakar, S. (2011) Antiviral Activity of Four Types of Bioflavonoid against Dengue Virus Type-2. Virology Journal, 8, 560. https://doi.org/10.1186/1743-422X-8-560

[6] Hubbard, G.P., Wolffram, S., Lovegrove, J.A. and Gibbins, J.M. (2004) Ingestion of Quercetin Inhibits Platelet Aggregation and Essential Components of the Colla- 
gen-Stimulated Platelet Activation Pathway in Humans. The Journal of Thrombosis and Haemostasis, 2, 2138-2145. https://doi.org/10.1111/j.1538-7836.2004.01067.x

[7] Wulandari, L., Retnaningtyas, Y. and Lukman, H. (2016) Analysis of Flavonoid in Medicinal Plant Extract Using Infrared Spectroscopy and Chemometrics. Journal of Analytical Methods in Chemistry, 2016, Article ID: 4696803.

https://doi.org/10.1155/2016/4696803

[8] Stuart, B. (2004) Infrared Spectroscopy: Fundamentals and Applications. Analytical Techniques in the Sciences, Wiley, Hoboken, 1-203.

https://doi.org/10.1002/0470011149

[9] Clas, S.-D., Dalton, C.R. and Hancock, B.C. (1999) Differential Scanning Calorimetry: Applications in Drug Development. Pharmaceutical Science \& Technology Today, 2, 311-320. https://doi.org/10.1016/S1461-5347(99)00181-9

[10] Holler, F.J., Skoog, D.A. and Crouch, S.R. (2007) Principles of Instrumental Analysis, Sixth Edition. International Student Edition, Brooks/Cole, Pacific Grove, 1-1039.

[11] Wang, L. and Weller, C.L. (2006) Recent Advances in Extraction of Nutraceuticals from Plants. Trends in Food Science and Technology, 17, 300-312.

https://doi.org/10.1016/j.tifs.2005.12.004

[12] Fernandes, F.H.A., Santana, C.P., Santos, R.L., Correia, L.P., Conceição, M.M., Macêdo, R.O. and Medeiros, A.C.D. (2012) Thermal Characterization of Dried Extract of Medicinal Plant by DSC and Analytical Techniques. Journal of Thermal Analysis and Calorimetry, 113, 443-447. https://doi.org/10.1007/s10973-012-2807-3

[13] Banerjee, S. and Chatterjee, J. (2014) Efficient Extraction Strategies of Tea (Camellia sinensis) Biomolecules. Journal of Food Science and Technology, 52, 3158-3168. https://doi.org/10.1007/s13197-014-1487-3

[14] Cheng, S.Z.D., Li, C.Y., Calhoun, B.H., Zhu, L. and Zhou, W.W. (2000) Thermal Analysis: The Next Two Decades. Thermochimica Acta, 355, 59-68. https://doi.org/10.1016/S0040-6031(00)00437-8

[15] Hatakeyama, T. and Quinn, F.X. (1994) Thermal Analysis; Fundamentals and Applications to Polymer Science. John Wiley \& Sons, New York.

[16] Craig, D.Q.M. and Reading, M. (2007) Thermal Analysis of Pharmaceuticals. CRC Press, Boca Raton.

[17] Kumar, P.R., Rajeevkumar, R. and Anbazhagan, S. (2012) Studies on Carica papaya Starch as a Pharmaceutical Excipient. Journal of Chemical and Pharmaceutical Research, 4, 3134-3138.

[18] Raymond, C.R. (2006) Handbook of Pharmaceutical Excipient. Sixth Edition, Pharmaceutical Press, London, 118-121, 581-585.

[19] Roy, A., Bahadur, S., Chanda, R. (2014) Natural Excipient Development: Need and Future. Asian Journal of Pharmaceutical Research, 4, 12-15.

[20] Horbowicz, M. (2002) Method of Quercetin Extraction from Dry Scales of Onion. Vegetable Crops Research Bulletin, 57, 119-124.

[21] Sultana, B., Anwar, F. and Ashraf, M. (2009) Effect of Extraction Solvent/Technique on the Antioxidant Activity of Selected Medicinal Plant Extracts. Molecules, 14, 2167-2180. https://doi.org/10.3390/molecules 14062167

[22] Mallamace, F., Corsaro, C., Mallamace, D., Vasi, S., Vasi, C., Baglioni, P., Buldyrev, S.V., Chen, S.-H. and Stanley, H.E. (2016) Energy Landscape in Protein Folding and Unfolding. Proceedings of the National Academy of Sciences, 113, 3159-3163. https://doi.org/10.1073/pnas.1524864113 


\section{Supplementary Data}

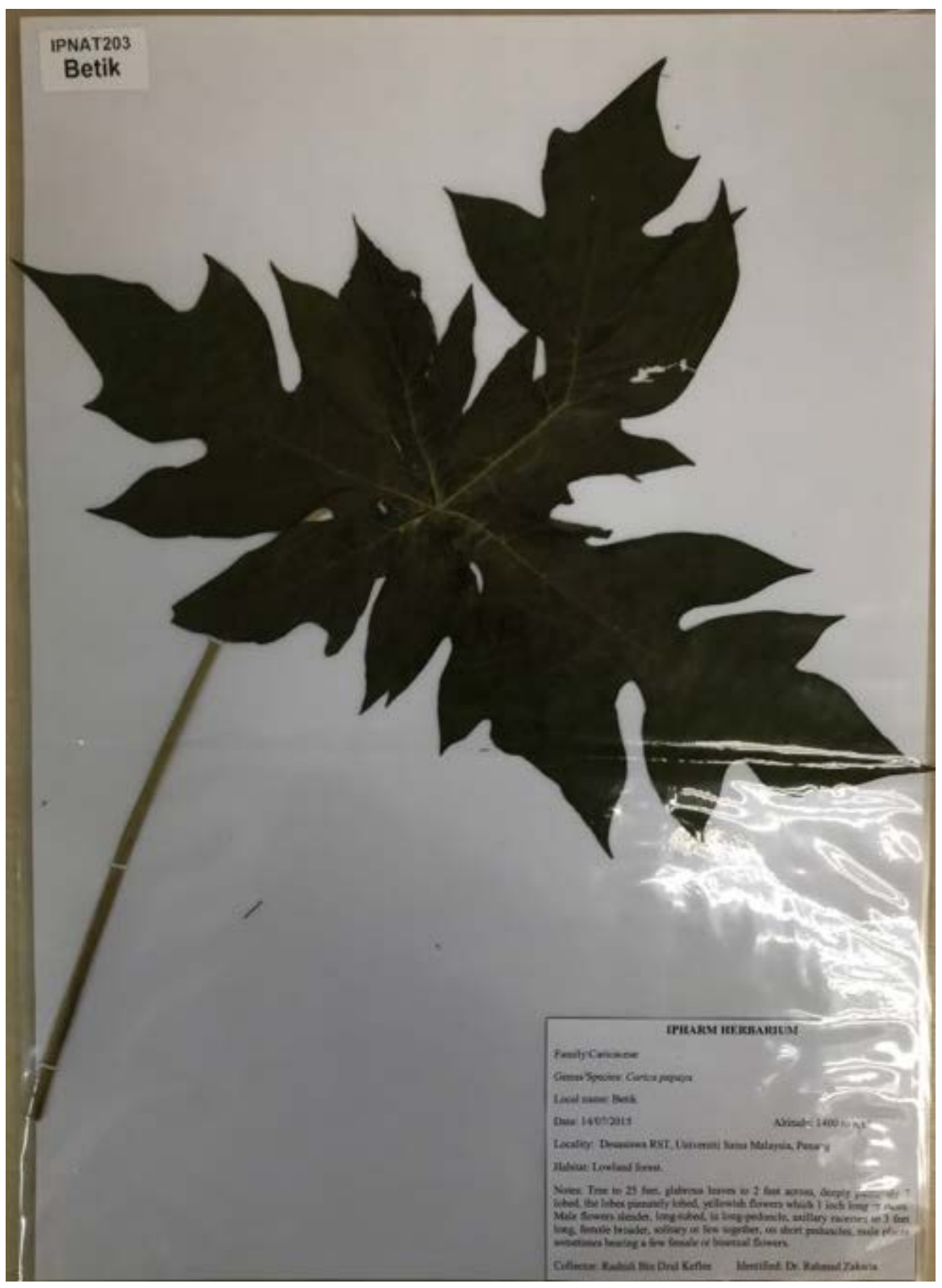




\section{List of Abbreviations}

FTIR-Fourier Transform Infra Red

HPLC-High Performance Liquid Chromatography

DSC-Differential Scanning Calorimetry

$\mathrm{Au}$-Absorbance unit

mg-milligram

g-gram

$\mu \mathrm{g}$-microgram

$\mu \mathrm{L}-$ microlitre

$\mu \mathrm{m}$-micrometre

$\mathrm{mm}-$ millimetre

$\mathrm{mL}-$ millilitre

$\mu \mathrm{g} / \mathrm{mL}$-microgram per millilitre

$\mathrm{mL} / \mathrm{min}-$ millimetre per minute

$\mathrm{nm}$-nanometre

${ }^{\circ} \mathrm{C}$-degree Celcius

$\%$-percentage

I.D.-internal diameter

$\mathrm{cm}^{-1}$ - centi per metre

ppm-part per million

RSD-Relative Standard Deviation

L-Litre

kg-kilogram

mg一milligram

$\geq-$ equal to and more than

$\mathrm{J} / \mathrm{g}$-Joule per gram 